\title{
粘土の非排水せん断時の間げき水圧に関する一考察*
}

\section{A CONSIDERATION ON THE PORE PRESSURE IN CLAYS UNDER UNDRAINED SHEAR}

\section{1. まえがき}

従来, 多くの粘土地盤の設計計算に, 飽和粘土が非排 水状態でせん断されるときに発揮する強さを用いてき た。このいわゆる $q_{u}$ 強度を支配するのは, 究極的には 破壊時の間げき水圧である。破壊時の間げき水圧につい ての表現方法は, Skempton ${ }^{1)}$ や Henkel $^{2)}$ によってそれ ぞれ,

$$
\begin{aligned}
& \Delta u=B\left\{\Delta \sigma_{3}+A_{f}\left(\Delta \sigma_{1}-\Delta \sigma_{3}\right)\right\} \\
& A_{f}=\frac{\sqrt{2}}{3}\left(\frac{D}{C}\right)_{f}+\frac{1}{3}
\end{aligned}
$$

および

$$
\begin{aligned}
\Delta u= & \left(\Delta \sigma_{1}+\Delta \sigma_{2}+\Delta \sigma_{3}\right) / 3 \\
& +a \sqrt{\left(\Delta \sigma_{1}-\Delta \sigma_{2}\right)^{2}+\left(\Delta \sigma_{2}-\Delta \sigma_{3}\right)^{2}+\left(\Delta \sigma_{3}-\Delta \sigma_{1}\right)^{2}}
\end{aligned}
$$

の形で示されている。ただし, 式 (1) は $\sigma_{2}=\sigma_{3}$ の場 合を想定している。土の破壊時の間げき水圧をどのよう な形で表現しようが，実用上はあまり問題にならない。 しかし， $D / C, B, a$ を定数とすると，式 (1)，(2) は 破壊時における間げき水圧だけしか表現できない。筆者 らはあくまで工学的立場に立ちながら, 正規圧密粘土の せん断中の間げき水圧の挙動を説明するための一つの仮 説をたて，実験值と比較検討した。それによると，せん 断中の間げき水圧の微小変化 $\Delta u$ は $\sigma_{2}=\sigma_{3}$ の場合,

$$
\begin{aligned}
& \Delta u=B\left\{\Delta \sigma_{3}+A^{\prime}\left(\Delta \sigma_{1}-\Delta \sigma_{3}\right)\right\} \\
& A^{\prime}=1 /\left\{(1-n) C / D-\left(\sigma_{1}-\sigma_{3}\right) / \sigma_{m}{ }^{\prime}\right\}+1 / 3
\end{aligned}
$$

と表わせることがわかった。ただし, 式 (3) 中の $\Delta$ は 式 (1)，（2）の $\Delta$ よりはずっと微小なものを意味して おり，式（3）を積分した形で得られるuが式 (1), (2)の $\Delta u$ に相当する。また， $B$ は Skempton の間げ き水圧係数 $B$ と同一で $(1-n) C / D$ は土の骨組構造に よってきまる係数であるが，正規圧密粘土ではせん断中 ほぼ一定であるとみなしてよい。

\section{2. 応力と体積変化}

粘土のクリープ試験やリラクゼーション試験の結果な

* 昭和 42 年度土木学会関西支部年次学術講演会において一 部発表

** 正会員 工博 京都大学教授 工学部土木工学教室

*** 学生員京都大学大学院修士課程
畠昭治郎**.太田秀 樹*** By Shōjirō Hata and Hideki Ōta

ぞから考えると，間げき水圧は変形掞よび変形速さの関 数として表わされるのが一般的であると考えられる。し かし, 変形に関して未知の領域の多い現在の段階では, 一般的な変形を取り扱うことが困難であるため，筆者ら は応力と変形が 1 対 1 に対応するような場合に対し, 間 げき水圧を応力の関数として表わした。応力の表示とし ては有効応力を用いたが, 有効応力は厳密にいえば間げ き水圧の関数であって, 非常にミクロな問題を取り扱う 場合には適当でない3)。ただ工学的な意味で便利である ために有効応力を使うのであるから，そこから導かれる 仮説も厳密さにおいてある制限をうけている。

排水状態の粘土をせん断すると体積変化が生ずる。一 般に体積変化は等方圧力によるものと, せん断応力によ るものとにわけて考えられるが，せ九断中にはそれらの 体積変化がおのおの独立して生ずるという保証はなく， 互いに影響しあいながら，せん断過程における各微小段 階で, ある平衡からつぎの平衡へ移行していくと考えら れる。それゆえ, せん断中の体積変化は等方圧力による ものとせん断応力によるものとを加えあわせるだけでは 表わすことができない。しかし，せん断過程における各 微小段階において，等方圧力とせん断応力の微小変化量 に伴って生ずる微小体積変化を加えあわせてその段階の 体積変化とするならば, 誤差は許容しらると考えられ る。以後, 筆者らの提案する仮説を述べるにあたって の文字を使用する が, それらは微小変 化を意味するものと する。

(1) 等方圧力に よる体積変化

排水を許す状態で 粘土に等方圧力をか けたときにみられる 体積変化が, 図一1 のようになることは 周知の事実である。 処女圧密領域で次式 図-1e-log $\sigma_{m}^{\prime}$ curve.

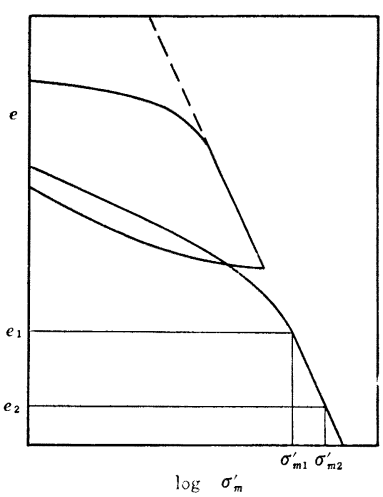
が成立する。

$$
e_{2}-e_{1}=-C_{c} \log _{10}\left(\sigma_{m 2}{ }^{\prime} / \sigma_{m 1}{ }^{\prime}\right)
$$


ここで添字 1,2 は処女圧密曲線上の $e_{2}<e_{1}$ を満足す るような任意の 2 点を示し， $C_{c}$ は圧縮指数である。い ま， 1,2 がきわめて近接した 2 点を示す場合には，

$$
\begin{aligned}
\Delta e_{1} & =e_{1}-e_{2}=C_{c} \log _{10}\left(\sigma_{m 2}{ }^{\prime} / \sigma_{m 1}{ }^{\prime}\right) \\
& =C_{c} \log _{10}\left\{\left(\sigma_{m 1}{ }^{\prime}+\Delta \sigma_{m 1}{ }^{\prime}\right) / \sigma_{m 1}{ }^{\prime}\right\}
\end{aligned}
$$

となり，点 1 は任意であるから添字を省略しても一般性 を失わない。それゆえ，式（5）はつぎのように書くこ とができる。

$$
\begin{aligned}
\Delta e & =C_{c} \log _{10}\left\{\left(\sigma_{m}{ }^{\prime}+\Delta \sigma_{m}{ }^{\prime}\right) / \sigma_{m}{ }^{\prime}\right\} \\
& =C_{c} \log _{10}\left(1+\Delta \sigma_{m}{ }^{\prime} / \sigma_{m}{ }^{\prime}\right) \quad \cdots
\end{aligned}
$$

$\Delta \sigma_{m}{ }^{\prime}$ は $\sigma_{m}{ }^{\prime}$ にくらべてきわめて小さいから, 自然対数 の底を $\varepsilon$ とすると,

$$
1+\Delta \sigma_{m}{ }^{\prime} / \sigma_{m}{ }^{\prime} \fallingdotseq \varepsilon^{\Delta \sigma_{m^{\prime}} / \sigma_{m}}
$$

が成立し，これを式（6）に代入すると次式が得られ る。

$$
\begin{aligned}
\Delta e & =C_{c} \log _{10} \varepsilon^{\Delta \sigma_{m^{\prime}} / \sigma_{m}{ }^{\prime}}=C_{c} \cdot \Delta \sigma_{m}{ }^{\prime} / \sigma_{m} \cdot \log _{10} \varepsilon \\
& =C \cdot \Delta \sigma_{m}{ }^{\prime} / \sigma_{m}{ }^{\prime} \ldots \ldots \ldots \ldots \ldots \ldots \ldots \ldots \ldots \ldots \ldots \ldots \ldots \ldots \ldots \ldots \ldots \ldots \ldots \ldots \ldots \ldots \ldots
\end{aligned}
$$

さらに,

$$
\Delta e=V_{v} / V_{s}=\Delta V / V_{s}
$$

であるから，

$$
\begin{aligned}
& \Delta V / V=\Delta e \cdot V_{s} / V=\left(V-V_{v}\right) / V \cdot \Delta e \\
& =(1-n) \Delta e
\end{aligned}
$$

となり $\Delta e$ に式 (8) を代入して

$$
\Delta V / V=C \cdot(1-n) \cdot \Delta \sigma_{m}{ }^{\prime} / \sigma_{m}{ }^{\prime}
$$

が得られる。以上は処女圧密曲線を利用して得た結果で あるが, 正規圧密粘土のように非排水せん断中に等方圧 力が減少する場合や, 膨張した過圧密粘土をさらに圧密 する場合などは, その状態に対态する $e-\log \sigma_{m}{ }^{\prime}$ 曲線の 平均的な傾き $C_{s}, C_{c r}$ を $C_{c}$ のかわりに代入して, 係 数 $C$ を求めればよい。ただし， $C_{s}, C_{c r}$ はそれぞれ除荷 時, 再載荷時の圧縮指数に対応するものである。また， 式 (11) をさらに一般的に取り扱うと, 係数 $C$ はかなら ずしも考えている応力範囲内で一定である必要はなく， ただ応力に従属していないことだけが必要な条件であ る。

以上が，排水を許す状態の粘土に働く等方圧力が微小 変化した場合に生ずる体積変化を与えるものとして, 筆 者らが提案する考え方である。

\section{(2) ダイレイタンシー}

せん断変形にともなう体積変化をダイレイタンシーと 一般に呼んでいる。これを定量的に研究するために, 柴 田 ${ }^{4)}$ は正規圧密粘土に対し, $\sigma_{m}{ }^{\prime}$ を一定に保ちながら排水 せん断試験を行なった。かれは乱さない尼崎粘土（L.L. $=105.5 \%$, P.L. $=32.4 \%$, P.I. $=73.1 \%$, $w=74.0 \%$, 最大先行圧縮応力 $\sigma_{0}{ }^{\prime}$ ) を $\sigma_{m}{ }^{\prime}>\sigma_{0}{ }^{\prime}$ なる $\sigma_{m}{ }^{\prime}$ で圧密し たのち, $\sigma_{m}{ }^{\prime}$ を一定に保ちながら 主応力差を増大させて 排水せん断を行なった。その結果は 図一2〜図一5 に示 されている。ダイレイタンシーと応力比 $\left(\sigma_{1}-\sigma_{3}\right) / \sigma_{m}{ }^{\prime}$ と
図-2 Volume change due to the change of shear stress (after Shibata)

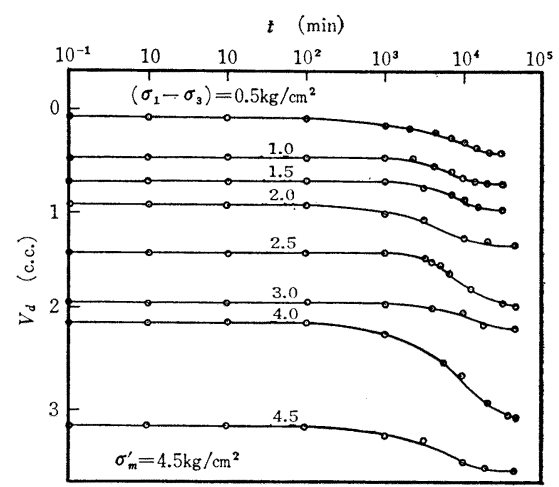

図-3 Stress-strain curves (a) and Dilatancystrain curve (b) (after Shibata)

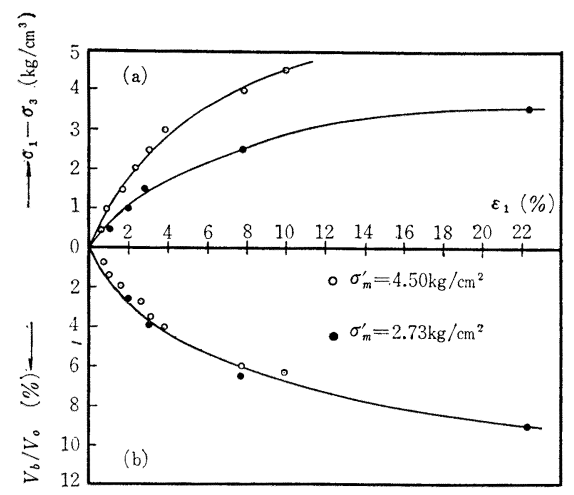

図-4 Stress ratio $\left(\sigma_{1}-\sigma_{3}\right) / \sigma_{m^{\prime}}{ }^{\prime}$ strain curve (after Shibata)

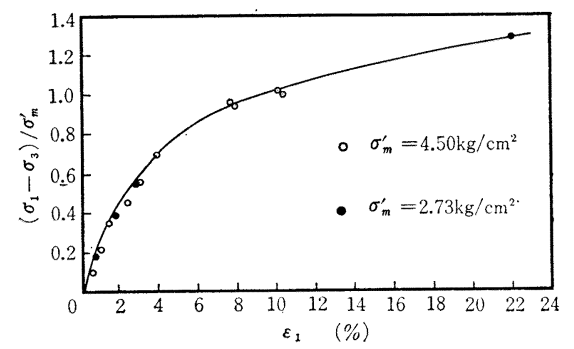

の直線的関係をさらに確かめるために，かれは Henkel (London Clay, Weald Clay) ${ }^{2)}$ および水野ら（福岡粘 土 ${ }^{5)}$ の実験結果を再整理して 図一6 を得ている。これ らの実験は三軸緩速試験, 圧密急速試験（間げき水圧測 定）で，平均有効主応力 $\sigma_{m}{ }^{\prime}$ を一定に保ったものではな いが, Rendulic の応力表示法を利用して $\sigma_{m}{ }^{\prime}$ 一定の条 件に換算して整理してある。以上の実験的事実から，か れはつぎの結論を得た。

$$
V_{d} / V_{0}=D\left\{\left(\sigma_{1}-\sigma_{3}\right)-\sigma_{c}\right\} / \sigma_{m}{ }^{\prime}
$$

柴田はコンプレッションテストに対する実験結果を整 理して式 (12) を得たが，コンプレッションテストで 
图-5 Dilatancy-stress ratio relations (after Shibata)

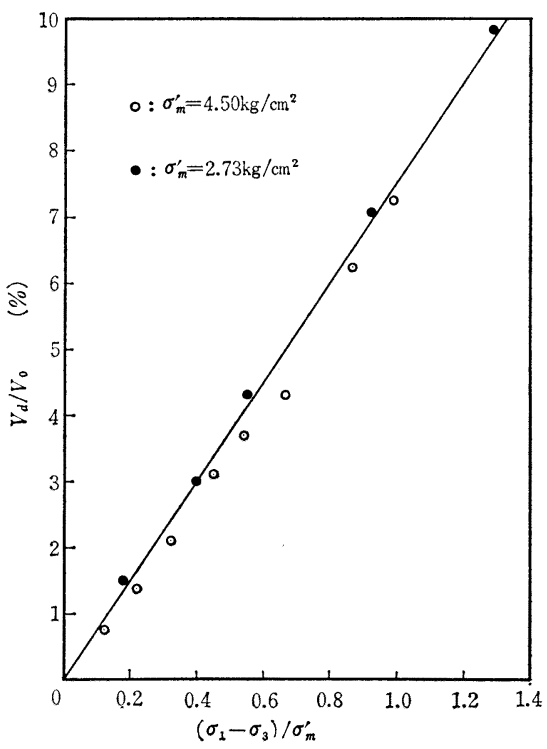

图-6 Dilatancy-stress ratio relations (after Shibata)

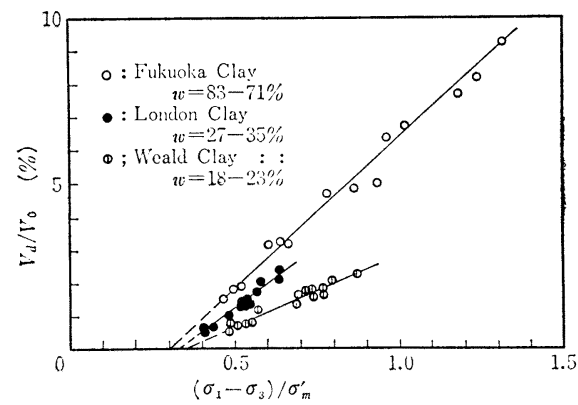

は $\sigma_{m}{ }^{\prime} \fallingdotseq \sigma_{N f^{\prime}}$ なる関係が近似的になりたつ。ただし， $\sigma_{N f^{\prime}}$ は潜在破壊面上での有効垂直応力である。それゆ え, 式 (12) において, 軸差応力の $\sigma_{m}{ }^{\prime}$ に対する比をと らず， $\sigma_{N f^{\prime}}$ に対する比をとっても同様の関係が得られ るであろう。またせん断の各段階で内部摩擦がもっとも 動員されている面上での有効垂直応力を $\sigma_{N m^{\prime}}$ とする と, $\left(\sigma_{1}-\sigma_{3}\right) / \sigma_{N m}{ }^{\prime}$ で整理しても同様の関係式が得られ る可能性も残されている。これらのいずれがよりよく事 実を説明するかという問題は, せん断の機構を探るらえ で重要である。この問題を確かめるために，筆者らが Henkel のエクステンションテストの結果(6)を再整理し たのが図一7 である。これから $\sigma_{N f^{\prime}}$ より $\sigma_{m}^{\prime}$ の方が 事実をよりよく説明できることがわかるが， $\sigma_{m}{ }^{\prime}$ で整理 した場合にも，コンプレッションとエクステンションで $D$ の值が異なる点に問題は残る。内部摩擦がもっとも動 員されている面が，せん断中にどのように回転するかに ついては未知な点が多いため, 工学的な立場から, 現在 の段階ではダイレイタンシーを式 (12) の形で表わすの
图-7 Dilatancy-stress ratio relations in extension test (rearranged from Henkel's data)

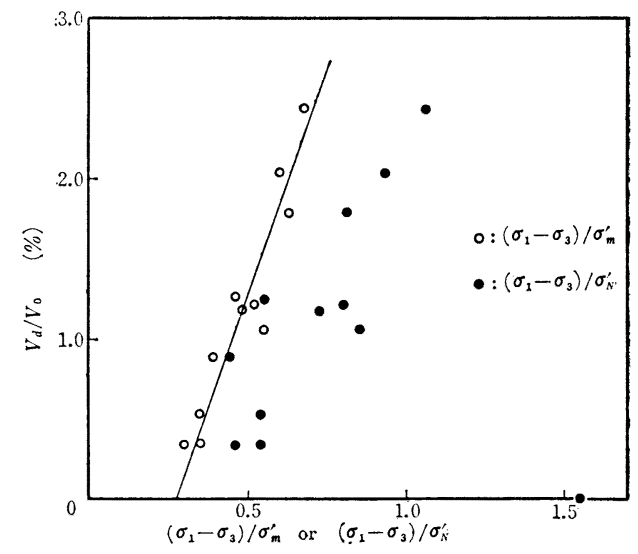

表-1 Values of $D$ and $\sigma_{c} / \sigma_{m}{ }^{\prime}$ in Eq. (12)

\begin{tabular}{l|c|r}
\hline \multicolumn{1}{c|}{ Clay } & $D$ & $\sigma_{c} / \sigma_{m}{ }^{\prime}$ \\
\hline Amagasaki Clay & $7.3 \times 10^{-2}$ & - \\
Fukuoka Clay & $9.2 \times 10^{-2}$ & 0.30 \\
London Clay & $7.7 \times 10^{-2}$ & 0.33 \\
Weald Clay Comp. & $4.5 \times 10^{-2}$ & 0.35 \\
\multicolumn{1}{c|}{ Ext. } & $5.6 \times 10^{-2}$ & 0.28 \\
\hline
\end{tabular}

がもっとも適当であると考えられる。以上の結果をまと めたのが表一1 であるが，表中の $\sigma_{c} / \sigma_{m}{ }^{\prime}$ は 図一6, 7 において直線が $\left(\sigma_{1}-\sigma_{3}\right) / \sigma_{m}{ }^{\prime}$ 軸をきる点であり，たとえ せん断応力が作用していても， $\left(\sigma_{1}-\sigma_{3}\right) / \sigma_{m}{ }^{\prime}$ が $\sigma_{c} / \sigma_{m}{ }^{\prime}$ に 達するまではダイレイタンシーが生じないことを意味す る。柴田の実験は図一2 からわかるように，1 段階に 2 週間近く時間をかけて排水しているのに対し, Henkel や水野らの実験は比較的せん断時間が短く, 排水がいく らか不完全であった可能性がある。筆者らが乱した粘土 を一面せん断試験機で圧密し，その後垂直圧力を増減さ せることによって，せん断中の試料の体積を一定に保ち ながら行なった圧密等体積せん断試験の結果の一例を図 -8 に示す。一面せん断試験機による試験結果は精度上 いろいろ問題があるが，三軸試験機の試料に比べて相当 小さい試料を用いるため，間げき水圧の測定に関する限 りでは，普通の三軸試験よりは敏感にその変化を記録す ることができるものと考えられる。図一8によれば，一

图-8 Stress path at constant volume test for normally consolidated clay.

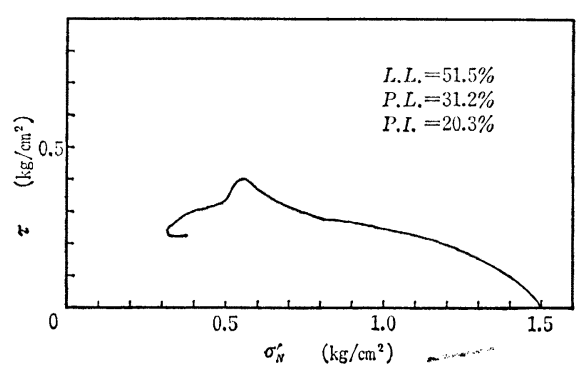


図-9 Dilatancy-stress ratio relation.

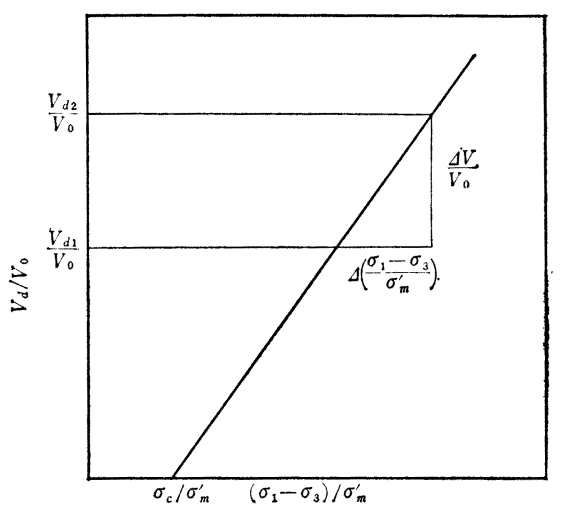

般の三軸非排水試験による結果にくらべて, せん断初期 の間げき水圧の発生がかなり著しい。以上のことからせ ん断中の排水が完全ならば， $\sigma_{c} / \sigma_{m}{ }^{\prime} \fallingdotseq 0$ となることが予 想される。図一5，6，7 を模式的に図化した図一9にお いて, ダイレイタンシーの微小変化を考えると次式がな りたつ。

$$
\Delta V / V \fallingdotseq \Delta V / V_{0}=D \Delta\left\{\left(\sigma_{1}-\sigma_{3}\right) / \sigma_{m}{ }^{\prime}\right\}
$$

$\Delta$ は微小量を意味し, $\sigma_{1}-\sigma_{3}$ と $\sigma_{m}^{\prime}$ は独立であるから 式 (13) より次式が得られる。

$$
\begin{aligned}
\Delta V / V= & D \Delta\left(\sigma_{1}-\sigma_{3}\right) / \sigma_{m}{ }^{\prime} \\
& -D \cdot\left(\sigma_{1}-\sigma_{3}\right) / \sigma_{m}{ }^{\prime} \cdot \Delta \sigma_{m}{ }^{\prime} / \sigma_{m}{ }^{\prime}
\end{aligned}
$$

式 (14) がダイレイタンシーの微小変化を与える式とし て, 提案する近似式である。式 (14) において係数 $D$ は, 正規圧密粘土では考えている応力範囲内において一 定であるが，一般には必ずしも一定である必要はなく， ただ応力に従属していないことだけが必要な条件であ る。

\section{（3）せん断に伴う体積変化}

粘土の排水せん断試験を行ならと, 等方圧力とせん断 応力による体積変化が同時に生じ，それらは互いに関係 しあいながら，せん断の進行に伴ってつぎつぎと新しい 平衡に移行する。それゆえ, 体積変化の機構は本節 （1），（2）で述べた機構のように簡単ではない。しか し, せん断過程中の非常に微小な各段階における体積変 化を式 (11) と式 (14) の和で近似してもよいと考える と,

$$
\begin{aligned}
\Delta V / V= & C(1-n) \Delta \sigma_{m}{ }^{\prime} / \sigma_{m}{ }^{\prime}+D \Delta\left(\sigma_{1}-\sigma_{3}\right) / \sigma_{m}{ }^{\prime} \\
& -D\left(\sigma_{1}-\sigma_{3}\right) / \sigma_{m}{ }^{\prime} \cdot \Delta \sigma_{m}{ }^{\prime} / \sigma_{m}{ }^{\prime} \\
= & \left\{C(1-n)-D\left(\sigma_{1}-\sigma_{3}\right) / \sigma_{m}{ }^{\prime}\right\} \Delta \sigma_{m}{ }^{\prime} / \sigma_{m}{ }^{\prime} \\
& +D \Delta\left(\sigma_{1}-\sigma_{3}\right) / \sigma_{m}{ }^{\prime} \cdots \cdots \cdots \cdots \cdots \cdots \cdots \cdots \cdots \cdots \cdots \cdots \cdots
\end{aligned}
$$

が得られる。 $\tau_{\text {oct }}=\sqrt{2}\left(\sigma_{1}-\sigma_{3}\right) / 3$ であるから式 (15) は つぎのように書きなおすこともできる。

$$
\begin{aligned}
\Delta V / V= & \{C(1-n) \\
& \left.-(3 / \sqrt{2}) \cdot D \cdot\left(\tau_{\text {oct }} / \sigma_{m}{ }^{\prime}\right)\right\} \Delta \sigma_{m}{ }^{\prime} / \sigma_{m}{ }^{\prime} \\
& +(3 / \sqrt{2}) \cdot D \cdot \Delta \tau_{\text {oct }} / \sigma_{m}{ }^{\prime} \cdots \cdots \cdots \cdots(16) \cdots \cdots(
\end{aligned}
$$

式 (16) において $C, D$ は後述するように土の骨組構造 によって支配される係数であり，応力には従属しないも のである。せん断の進行とともに土の骨組構造は変化す るから, 式 (16) に代入すべき $C, D$ は各微小段階によ って変化する。正規圧密粘土では，ストレスパスが破 壊包絡線に達するまでの間 $D$ はぼ一定であり, さらに $C$ も近似的に一定と考えて大きな誤りはない。一般にせ ん断中の体積変化を与える式 ${ }^{7)}$ として

$$
\Delta V / V=C^{\prime} \Delta \sigma_{m}{ }^{\prime}+D^{\prime} \Delta \tau_{\text {oct }}
$$

が用いられることがあるが，式（16）は式（17）に比べ てかなり複雑である。ただし, 式 (17) の $\Delta$ は必ずしも 微小を意味するわけではなく，せん断過程のある段階ま での総変化量を示している。

\section{3. せん断に伴う間げき水圧}

2. では粘土の排水せん断に伴う体積変化について述 べたが，本節では前節で提案した式を用いて，非排水せ ん断に伴ら間げき水圧の変化について考察する。非排水 状態であるから，式 (16) の左辺を0 とおけば,

$$
\begin{gathered}
\left\{C(1-n)-(3 / \sqrt{2}) \cdot D\left(\tau_{\text {oct }} / \sigma_{m}{ }^{\prime}\right)\right\} \Delta \sigma_{m}{ }^{\prime} / \sigma_{m}{ }^{\prime} \\
\quad+(3 / \sqrt{2}) D\left(\Delta \tau_{\text {oct }} / \sigma_{m}{ }^{\prime}\right)=0 \cdots \cdots \cdots \cdots . .
\end{gathered}
$$

が得られる。非排水状態でのせん断と排水状態のせん断 とで土の骨組構造の変化すなわちせん断機構に大きな相 違があれば, 式 (18) は成立しない。しかし, 排水と非 排水ではせん断機構にある程度の相違は予想されるが, 本質的な相違があるとは考えられない。Rendulic の応 力図上にせん断中の粘土の忘力状態をプロットし, 等含 水比線を描くと（非排水せん断ではストレス パスその ものであるが), その幾何学的特徴は排水, 非排水の区別 なく一定であるという Henkel ${ }^{6)}$ の研究から考えて, 式 (18) は本質的には問題なく成立すると考えられる。ただ し, 式 (16) と式 (18) の係数 $C, D$ が若干異なること は予想される。式 (18) の両辺に $\sigma_{m}^{\prime}$ をかけると,

$$
\begin{aligned}
& \left\{C(1-n)-(3 / \sqrt{2}) \cdot D \cdot\left(\tau_{\text {oct }} / \sigma_{m}{ }^{\prime}\right)\right\} \Delta \sigma_{i n}{ }^{\prime} \\
& \quad+(3 / \sqrt{2}) \cdot D \cdot \Delta \tau_{\text {oct }}=0 \ldots \ldots \ldots \ldots \ldots \ldots . .
\end{aligned}
$$

が得られるが, 式 (17) の左辺を 0 とおいた形と類似し ているのは興味深い。式 (19) を $\sigma_{2}=\sigma_{3}$ として, $\Delta u$ に ついて解くと,

$$
\begin{aligned}
& \Delta u=B\left\{\Delta \sigma_{3}+A^{\prime}\left(\Delta \sigma_{1}-\Delta \sigma_{3}\right)\right\} \quad \cdots \cdots \cdots \cdots \cdots \\
& A^{\prime}=1 /\left\{(1-n) C / D-\left(\sigma_{1}-\sigma_{3}\right) / \sigma_{m}{ }^{\prime}\right\}+1 / 3
\end{aligned}
$$

が得られる。ここに $B$ は Skemptonによって与えられた 間げき水圧係数 $B$ であり, 飽和土では 1 である。式 (20) はせん断中の間げき水圧の挙動を与えるものとして提案 する式であるが, 係数 $(1-n) C / D$ を変化させることに より, 種々の状態にある種々の土のせん断中の間げき水 圧の挙動を表現することが可能である。間げき水圧に関 する従来の実験結果は, 前述のように精度の点で問題が 多いため, 係数 $(1-n) C / D$ の性質を知るには今後非常 
に精密な実験を数多く行なわなくてはならない。式 (20) の妥当性やその適用範囲は，それらの結果をもとにして 判断せねばならないから，それにはかなりの年月を要す るが，式（20）を導くために設けた仮定から考えて，こ の式は少なくとも粘性土に関しては成立するものと考え られる。

\section{4. 間げき水圧の挙動と土の骨組構造の関係}

式 (20) において, 係数 $(1-n) C / D$ は応力状態に従 属するものではない。多くの土のせん断試験の結果に対 し, 式 (20) を適用し, 係数 $(1-n) C / D$ の值を求める と, ストレス パスの幾何学的特徴が大きく変化すると きに係数の值も大きく変化する。同じ過圧密比をもつ同 種の粘土のストレス パスがほぼ相似である事実から考 えると, ストレス パスの幾何学的特徵の変化は応力状 態によるよりは, 粘土の骨組構造の変化によるものであ ることが予想され，さらに，図一10のような破壊包絡 線上のストレス パスの挙動はこの予想の妥当性を高め

図-10 Constant volume test with saturated sandy clay by shear box.

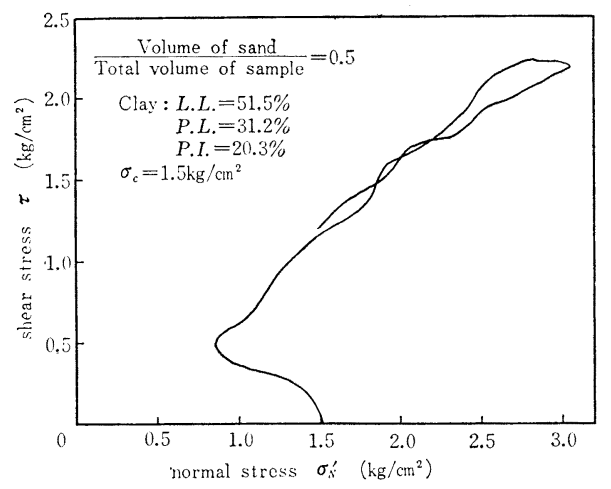

ている。また，同じ粘土を正規圧密状態でせん断した場 合と過圧密状態でせん断した場合とでは，応力状態が全 く同じでも間げき水圧の挙動は非常に異なる。この事実 からも係数 $(1-n) C / D$ が応力状態には従属せず, 土の 骨組構造によってきまるものであることが確かめられ る。以上のことから間げき水圧の挙動は土の骨組構造の 変化によって支配されることがわかる。従来から土の骨 組構造とせん断特性が密接に関係していることは指摘さ れていたが，種々の土のストレス パスから式 (20) を 用いて係数 $(1-n) C / D$ の変化を求めることにより，土 の骨組構造とせん断特性との関係を求めることが可能と なった。このように式 (20) は土のせん断機構そのもの の解明に重要な手がかりを与える。しかし, 現在までに 得られている実験結果の多くは，間げき水圧の測定がや や不完全であると思われるため, 従来のデータから係数 $(1-n) C / D$ と土の骨組構造との関係を 正確に知ること は困難である。それゆえ，次節では正規圧密粘土に関し
て, 両者の関係を非常に簡単な形に近似化して考察を加 える。

\section{5．正規圧密粘土に関する実験および考察}

正規圧密粘土について Henkel, 水野, および筆者ら のせん断試験の結果を用いて, 倸数 $(1-n) C / D$ のせん 断に伴う変化をしらべてみると，ストレスパスが破壊 包絡線に達するまでは係数 $(1-n) C / D$ の值はそれほど 大きく変化しないことが認められる。前述のように $\sigma_{m}{ }^{\prime}$ 一定の排水せん断ではDは一定であるから, 非排水せん 断においても大きく変化するとは考えられない。したが って, 正規圧密粘土の場合，Cはせん断中にあまり大き くは変化しないであろらと考えられる。Henkel や水野 の実験結果は 表一1 に示されたように, $\left(\sigma_{1}-\sigma_{3}\right) / \sigma_{m}{ }^{\prime}>$ $\sigma_{c} / \sigma_{m}{ }^{\prime}$ の場合にのみ式 (20) を満足する。せん断が進ん で $\left(\sigma_{1}-\sigma_{3}\right) / \sigma_{m}{ }^{\prime}>\sigma_{c} / \sigma_{m}{ }^{\prime}$ となり, 係数 $(1-n) C / D$ が ほぼ一定となった部分に対して, 平均的な係数の值を用 いて逆に $\Delta u$ を計算したのが 図-11 (a)，(b)である。

図-11 (a) Comporison between measured and calculated values of $\Delta u$.

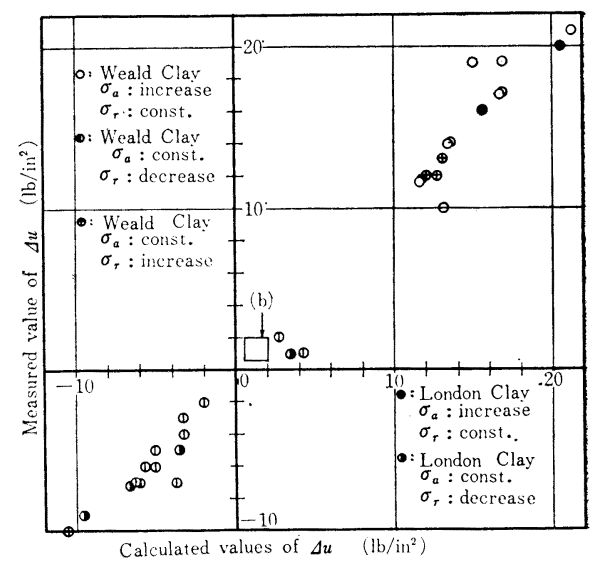

目-11 (b) Comparison between measured and calculated values of $\Delta \cdot u$.

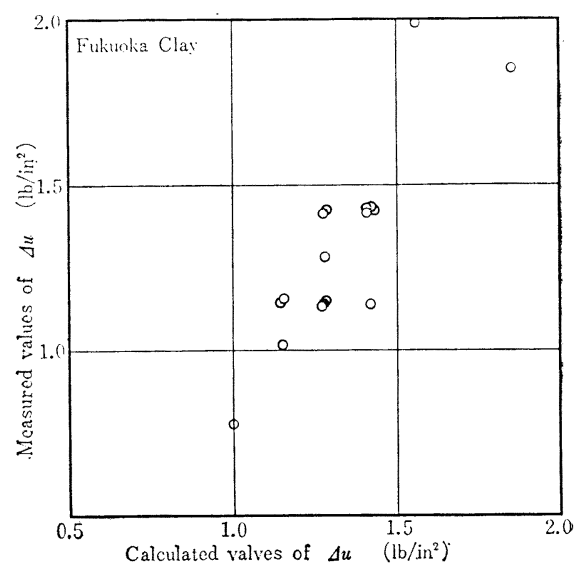


图-12 Stress paths at constant volume tests for normally consolidated specimens.

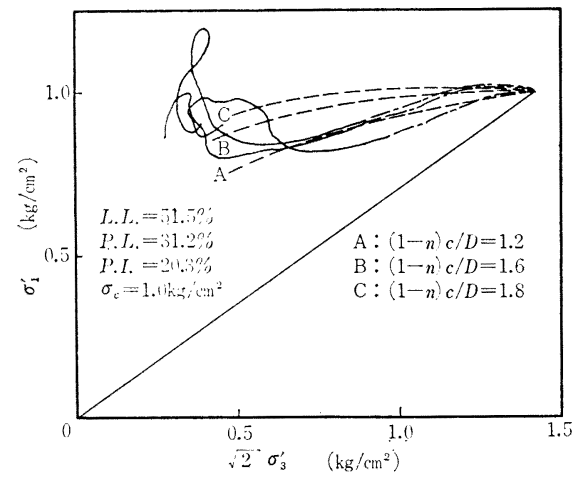

ただし, Weald Clay のエクステンション試験に対し ては資料が少ないため $w=18 〜 24 \%$ までの試料に対し て係数 $(1-n) C / D$ が一定として計算した。また, 福岡 粘土については $\Delta u$ が非常に小さく, (a) 図 に図示で きないため（b）図に記載してあるが， $\Delta u$ がきわめて 小さいためか係数 $(1-n) C / D$ を一定とした計算值には あまり合わないことがわかる。図一12 は筆者らが正規 圧密粘土に対して一面せん断試験機を用いて体積を一定 に保ちながらせん断した結果である。一面せん断試験機 による間げき水圧の測定は, 試料が非常に小さいため三 軸試験に比べてきわめて敏感である。せん断過程におけ る $\tau-\sigma_{N}{ }^{\prime}$ 図上のストレス パスの各点は, 内部摩擦が 最も動員されている面上での応力状態を示すものと考え られるから，図一13 のような方法で $\sigma_{1}{ }^{\prime}, \sigma_{3}{ }^{\prime}$ を求めた。 ただし,この場合せん断過程中一般に粘着力と呼ばれて いるものは全く発揮されないと仮定している。このよう にして求めた実験值は実線で示してあるが，せん断初期 において，間げき水王の発生は非常に急速で十分には測 定できないため鎻線で示してある。また係数 $(1-n) C / D$ に一定值を入れて計算した結果は点線で示してある。こ れらの実験結果加逆算した係数 $(1-n) C / D$ は, せん 断に伴ってある一定の傾向をもって変化しているように もみえるが，実験結果そのものが精度的に問題があるた め, 係数 $(1-n) C / D$ を一定值とおいて近似したのであ る。

Henkel の実騃結果より 求めた係数 $(1-n) C / D$ は $n$ が大きい粘土ほど増大する傾向をもつ。 $\sigma_{m}{ }^{\prime}$ 一定の排水

図-13 Mohr's circle

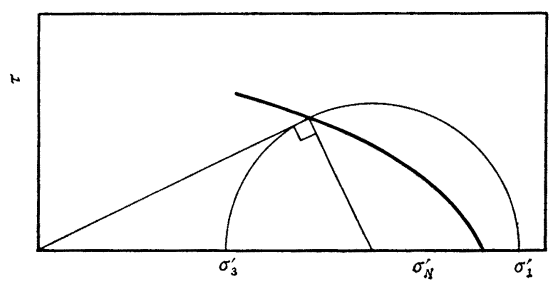

せん断では $D$ は間げき率 $n$ に無関係に一定であったか ら，nが増大するにしたがってCが増大していると考え られる。正規圧密粘土では非排水せん断中に $\sigma_{m}{ }^{\prime}$ は減少 するから, この傾向は圧密の $e-\log \sigma_{m}{ }^{\prime}$ 曲線の除荷時 の傾きの性質に関係していると考えられる。今後, さら に精密な実験を行なって, せん断に伴う土の骨組構造の 変化と係数 $(1-n) C / D$ の関係を研究する必要がある が, 現在の段階では正規圧密粘土のせん断に伴う間げき 水圧は, 係数 $(1-n) C / D$ を一定として計算しても大き な誤りはないと考えられる。係数 $(1-n) C / D$ を一定と して, $\Delta \sigma_{3}=0$ の場合に対して式 (20) を積分し, せん断 に伴う間げき水圧 $u$ を表わす式を導くと, 対数の形の項 を含み, 水野らが正規圧密粘土のせん断中のストレス パスを対数カーブで近似できると述べていることと一致 する。

\section{6. 土構造物の施工と間げき水圧の挙動}

まえがきに述べたように，土構造物の設計にあたって は破壊時の間げき水圧を知ることが必要である。しか し, 土構造物を安全に施工するには施工中の土構造物の 変化に細心の注意を払わねばならない。したがって, 士 構造物の施工にあたる技術者はせん断されつつある土中 の間げき水圧の挙動に関してある程度の知識をもってい る必要がある。

トンネルの支保工や土留めの矢板などは, 土構造物の 築造において破壊を防止するために一時的にとられる処 置であるが, 経済的な理由からこれらの処置には常に十 分の安全率を見込んであるとは限らない。それゆえ, 施 工時には支保工や矢板の変形の状態を監視し, 危険と思 われる場合には補強しなくてはならない。しかし, 肉眼 だけで監視していると, 土の応力状態や破壊への進行の 度合を適確に把握することが困難で, 補強が遅れたり, または過大になることがあるから, 土の状態を適確に把 握する方法の出現が望まれている。土の状態を知るため の目安としては, ひずみ, ひずみ速度, 間げき水圧など があるが, 間げき水圧は実際上測定が非常に困難で, 実 測值が信頼できないため, ある程度理論的に推定しなく てはならない。式 (20) はこのような問題に対し, 解決 のための一つのいとぐちを与えるものである。

土構造物の施工にあたる技術者は施工中の構造物の変 形や変形速度を監視するらえに, 進行性破壊についての 知識をもつことが望ましい。たとえば，粘土地盤の斜面 の模型を，破壊面上での間げき水圧を測定しながら破壊 させることができれば, 式 (20) により破壊面上の各点 の忘力状態を推定することができる。その結果から進行 性破壊と粘土の骨組構造の変化に関する知識が得られる ばかりでなく, 設計の際に用いる応力分布の妥当性を確 かめることができる。 
図一10 は粘土の中に砂を混ぜ，砂の体積が圧密後の 全体積の $50 \%$ になるように調整した試料を, 一面せん 断試験機を用いて等体積せん断した結果である。地山中 にトンネルを掘削するような場合, 地山が岩塊やれきと 土との混合体と考えられる場合も多い。そのような場合 には地山のせん断特性はおそらく図一10のような傾向 を示すであろう。松尾・軽部 ${ }^{8)}$ は不飽和土のせん断を例 にとり非常に浅い基礎のように体積変化に対する拘束力 が小さい場合には，ストレス パスが破壊包絡線に達し たのちに, さらに発揮されるせん断抵抗力は常に期待し らるとは限らないと考え, 設計にはストレスパスが破 壞包絡線に達したときのせん断抵抗力を目安にすべき場 合があると述べている。しかし，土かぶりの大きいトン ネルなどはせん断中の体積変化に対する拘束が大きいと 考えられ，ストレス パスが破壊包絡線に達してからさ らにどの程度のせん断抵抗力の増加が期待できるかとい う問題に対して大体の目安をもつことは，施工にあたる 技術者にとって非常に望ましいことである。前述の土の 骨組構造の変化とせん断特性の関係がある程度解明され れば,このような問題に対しても有益な示唆を与えるこ とができるであろう。

以上に述べたように，土構造物の施工をより確実に遂 行するためには，施工中の土構造物の変化に関する知識 が不可欠である。筆者らはこのような問題を解決するた めの一つのいとぐちを得るために式（20）を導いたので あるが，今後の土質力学の発展に寄与できれば幸いであ る。

\section{7.むすび}

粘性土，特に正規圧密粘土のせん断中の間げき水圧の 変化について考察したが, 以上の結論をまとめるとつぎ のようになる。

（i）粘性土のダイレイタンシーについては, 破壊面 上の垂直応力 $\sigma_{N f^{\prime}}$ で整理するより, 平均主応力 $\sigma_{m}{ }^{\prime}$ で整理したほうが事実をよりよく表現できる ようである。

（ii）粘土のせん断を三軸試験機で行なう場合，従来 は一週間以内でせん断を完了していたが，間げき
水圧を正確に測定するためには，従来よりさらに 緩速で行なったほうがよいと考えられる。

(iii） 粘性土のせん断中の間げき水圧の微小変化 $\Delta u$ は次式で与えられる。

$$
\begin{aligned}
& \Delta u=B\left\{\Delta \sigma_{3}+A^{\prime}\left(\Delta \sigma_{1}-\Delta \sigma_{3}\right)\right\} \\
& こ こ に, \\
& A^{\prime}=1 /\left\{(1-n) C / D-\left(\sigma_{1}-\sigma_{3}\right) / \sigma_{m}{ }^{\prime}\right\}+1 / 3
\end{aligned}
$$

正規圧密粘土に対しては係数 $(1-n) C / D$ はせん 断中（条件付きで）ほぼ一定である。

(iv) 係数 $(1-n) C / D$ は土の骨組構造の性質を示す ものであることが予想され，両者の関係をくわし く調べることは今後の課題である。しかし，従来 の間げき水圧の測定結果は精度上問題が多いた め, 今後さらに精密な測定結果を得ることが必要 である。

終りにあたり，多くの助言を頂いた京都大学柴田徹助 教授，同松尾稔助教授に対し心から謝意を表する。

\section{考文 献}

1) Skempton, A.W : The Use of Pore Pressure Coefficients $\mathrm{A}$ and $\mathrm{B}$, Géotechnique, Vol. 4, No. 4 (1954), pp. 143-147.

2) Henkel, D.J.: The Shear Strength of Saturated Remoulded Clays, Research Conference on Shear Strength of Cohesive Soils, ASCE (1960), pp. 533554.

3) Bishop, A.W.: The Principle of Effective Stress, Norwegian Geotechnical Institute Publication No. 32 (1960) pp. 1-5.

4）柴田 徹：粘土のダイラタンシーについて, 京都大学防災 研究所年報 6 号 (1963), p. 128-134.

5）水野高明, 德光善治, 川上 浩 : 三軸試験中の間げき水 圧の挙動について”, 土木学会第 17 回年次学術講演会概 要 III (1962), p. 25-26.

6) Henkel, D.J. : The Relationships Between the Effective Stresses and Water Content in Saturated Clays, Géotechnique, Vol. 10 (1960) pp. 41-54.

7) Skempton, A.W.: The Pore-Pressure Coefficient in Saturated Soils, Géotechnique, Vol. 10 (1960) pp. 186-187.

8）松尾 稔・軽部大蔵 : 室内セン断試験結果の設計への適 用に際する 2,3 の問題点, 第 11 回土質工学シンポジ ウム発表論文集 (1966) p. 91-100.

（1967. 10.6.受付） 